\title{
PENGARUH PRODUK DOMESTIK REGIONAL BRUTO (PDRB), TINGKAT PENDIDIKAN DAN PENGANGGURAN TERHADAP TINGKAT KEMISKINAN DI PROVINSI SUMATRA BARAT
}

\author{
${ }^{1}$ Patria Nagara, ${ }^{2}$ Misharni, ${ }^{3}$ Syofria Meidona \\ 1'patrianagara@gmail.com, ${ }^{2}$ misharni77@yahoo.co.id, ${ }^{3}$ syofriameidona@gmail.com
}

Fakultas Ekonomi Universitas Sumatera Barat

\section{ABSTRACT}

The purpose of this research is to analyze the influence of PDRB growth, education level, and unemployment rate towards poverty level in West Sumatra Province district. This research uses quantitative descriptive methods with multiple regression approaches. This method is to determine and analyze how PDRB growth, education, and unemployment to poverty levels in Sumatra Province. Based on the results of the study showed that (1) the variable PDRB (X1) positively affects the level of poverty in Sumatra Province for $0.003<$ 0.05. This indicates that there is a variable influence of PDRB on poverty in Sumatra Province. Then based on the results of the study showed that (2) the level of education (X2) variable has no effect on the level of poverty in Sumatra Province. of $0.029>0.05$. This indicates that there is no influence between the variable level of education to the poverty level in Sumatra Province. And then based on the results shows that the variable (3) unemployment (X3) affects the poverty of Sumatra Province. of $0.005<0.05$. This indicates there is a variable influence on unemployment in poverty in Sumatra Province. The results showed that PDRB was positively influential in poverty, education had no positive effect on poverty and unemployment had positive effect on poverty.

Keywords: GRDP, level of education, level of unemployment and poverty level.

\section{ABSTRAK}

Tujuan dari penelitian ini adalah untuk menganalisis pengaruh pertumbuhan PDRB, tingkat pendidikan, dan tingkat pengangguran terhadap tingkat kemiskinan di Provinsi Sumatra Barat. Penelitian ini menggunakan metode deskriptif kuantitatif dengan pendekatan regresi berganda. Metode ini adalah untuk menentukan dan menganalisis bagaimana pengaruh pertumbuhan PDRB, pendidikan, dan pengangguran terhadap tingkat kemiskinan di Provinsi Sumatra Barat. Berdasarkan hasil penelitian menunjukkan bahwa (1) variabel PDRB (X1) berpengaruh positif Pada tingkat Kemiskinan di Provinsi Sumatra Barat sebesar 0,003<0,05. Hal ini menunjukkan ada pengaruh variabel PDRB terhadap Kemiskinan di Provinsi Sumatra Barat. Kemudian Berdasarkan hasil penelitian menunjukkan bahwa (2) variabel Tingkat Pendidikan (X2) tidak berpengaruh terhadap tingkat Kemiskinan di Provinsi Sumatra Barat. sebesar 0,029 > 0,05. Hal ini menunjukkan tidak ada pengaruh antara variabel Tingkat Pendidikan terhadap tingkat Kemiskinan di Provinsi Sumatra Barat. Dan Kemudian Berdasarkan hasil penelitian menunjukkan bahwa variabel (3) Pengangguran (X3) berpengaruh terhadap Kemiskinan Pada Provinsi Sumatra Barat. sebesar 0,005 < 0,05. Hal ini menunjukkan ada pengaruh variabel Pengangguran terhadap Kemiskinan di Provinsi Sumatra Barat. Hasil penelitian menunjukkan bahwa PDRB berpengaruh positif terhadap tingkat kemiskinan, pendidikan tidak berpengaruh positif terhadap kemiskinan dan pengangguran berpengaruh positif terhadap kemiskinan.

Kata Kunci: PDRB, Tingkat Pendidikan, Tingkat Pengangguran dan Kemiskinan

PENDAHULUAN
Persoalan kemiskinan yang masih besar dan kian kompleks menjadi tantangan pembangunan yang dihadapi Indonesia. Persoalan kemiskinan 
menjadi persoalan yang serius karena konsekuensi yang ditimbulkannya. Kemiskinan menyebabkan jutaan rakyat memenuhi kebutuhan pangan, sandang dan papan secara terbatas. Kemiskinan juga mengakibatkan jutaan anak-anak tidak bisa memperoleh haknya untuk mengenyam pendidikan yang berkualitas, kesulitan rakyat untuk membiayai layanan kesehatan, kurangnya tabungan dan tidak ada investasi, kurangnya akses ke pelayanan publik, kurangnya lapangan pekerjaan, kurangnya jaminan sosial dan perlindungan terhadap keluarga, serta menguatnya arus migrasi ke kota..

Faktor lain yang menyebabkan kemiskinan adalah Produk Domestik Regoional Bruto (PDRB), merupakan salah satu faktor penting untuk mengetahui kondisi ekonomi disuatu daerah dalam suatu periode tertentu, baik atas dasar harga berlaku maupun atas dasar harga konstan. Produk Domestik Regional Bruto (PDRB) atas harga berlaku menggambarkan nilai tambah barang dan jasa yang dihitung menggunakan harga per tahun berjalan, sedangkan Produk Domestik Regional Bruto (PDRB) atas dasar harga konstan menunjukkan nilai tambah barang dan jasa dihitung menggunakan harga yang berlaku pada satu tahun sebagai tahun dasar.

Selain itu kemiskinan juga disebabkan oleh pengganguran, sehingga permasalahan antara pengangguran dan pendidikan sangat berkaitan dengan kualitas sumber daya manusia.

Sumatra Barat adalah sebuah provinsi di Indonesia yang terletak di Pulau Sumatra dengan Padang sebagai ibu kotanya. Provinsi Sumatra Barat terletak sepanjang pesisir barat Sumatra bagian tengah, dataran tinggi Bukit Barisan di sebelah timur, dan sejumlah pulau di lepas pantainya seperti Kepulauan Mentawai. dengan wilayah seluas $42.297,30 \mathrm{~km}^{2}$. Jumlah penduduk Provinsi Sumatra Barat tercatat sebanyak 5.382.077 jiwa.pada tahun 2018 .

Jumlah penduduk miskin di Provinsi Sumatra Barat cenderung semakin menurun dalam beberapa tahun terakhir, berdasarkan data BPS (Badan Pusat Statistik) kemiskinan di Provinsi Sumatra Barat mengalami penurunan dari tahun sebelumnya yaitu tahun 2017 sebesar 364.51 (ribu jiwa) menjadi 357.13 (ribu jiwa) pada tahun 2018.

\section{Identifikasi Masalah}

Berdasarkan latar belakang yang dijelaskan di atas, penulis mengidentifikasi masalah- masalah yang ada di dalam penelitian ini sebagai berikut :

1. Meningkatnya total Produk Domestik Regional Bruto (PDRB) mempengaruhi angka tingkat kemiskinan di Provinsi Sumatra Barat.

2. Tingginya jumlah penduduk yang menamatkan pendidikan jenjang SD, SMP dan SMA mempengaruhi angka kemiskinan di Provinsi Sumatra Barat.

3. Tingginya Tingkat Pengangguran Terbuka menandakan kenaikan jumlah angka kemiskinan di Provinsi Sumatra Barat.

\section{Batasan Masalah}

Melihat identifikasi masalah yang dipaparkan di atas, dan agar cakupan penelitian ini tidak terlalu luas dan tidak banyak menimbulkan penafsiran, maka penelitian ini dibatasi pada:

1. Data Produk Domestik Regional Bruto (PDRB) Provinsi Sumatra Barat dalam tujuh tahun terakhir .

2. Data jumlah Angka Partisipasi Kasar (APK), penduduk Provinsi Sumatra Barat jenjang pendidikan SD,SMP dan SMA dalam tujuh tahun terakhir.

3. Data Tingginya Tingkat Pengangguran Terbuka (TPT) Provinsi Sumatra Barat dalam tujuh tahun terakhir.

4. Data tingkat kemiskinan di Provinsi Sumatra Barat dalam tujuh tahun terakhir.

\section{Rumusan Masalah}

Berdasarkan latar belakang di atas, maka penulis mengambil suatu perumusan masalah sebagai berikut :

1. Apakah Produk Domestik Regional Bruto (PDRB) berpengaruh terhadap kemiskinan di Provinsi Sumatra Barat?

2. Apakah Angka partisipasi Kasar (APK) berpengaruh terhadap kemiskinan di Provinsi Sumatra Barat?

3. Apakah tingkat pengangguran berpengaruh terhadap kemiskinan di Provinsi Sumatra Barat?

\section{Tujuan Penelitian}

Adapun tujuan dalam penelitian ini adalah sebagai berikut :

1. Untuk mengetahui pengaruh Produk Domestik Regional Bruto (PDRB) terhadap kemiskinan di Provinsi Sumatra Barat. 
2. Untuk mengetahui pengaruh Angka Partisiapsi (APK) terhadap kemiskinan di Provinsi Sumatra Barat.

3. Untuk mengetahui pengaruh tingkat pengangguran terhadap kemiskinan di Provinsi Sumatra Barat.

\section{Manfaat Penelitian}

Adapun manfaat yang diperoleh penelitian ini adalah :

\section{Manfaat Teoritis}

a. Menambah wawasan di bidang pendidikan, terutama yang terkait dengan pengaruh Produk Domestik Regional Bruto (PDRB), Angka Partisipsi Kasar (APK) dan pengangguran terhadap pengangguran dan kemiskinan.

b. Diharapkan dapat menjadi salah satu acuan dalam melakukan penelitian yang akan dilakukan selanjutnya.

\section{Bagi peneliti}

diharapkan penelitian ini dapat menjadi salah satu bahan acuan baik dalam acuan belajar ataupun acuan untuk menentukan kebijakan ataupun penelitian yang akan dilakukan pembaca selanjutnya.

\section{TINJAUAN PUSTAKA}

\section{Pengertian Kemiskinan}

Menurut Hall dan Midgley (2010) pengertian kemiskinan adalah kondisi deprivasi materi dan sosial yang menyebabkan individu hidup di bawah standar kehidupan yang layak, atau kondisi di mana individu mengalami deprivasi relatif dibandingkan dengan individu yang lainnya dalam masyarakat.

Menurut BPS (2018) kemiskinan adalah ketidakmampuan dari sisi ekonomi, materi dan fisik untuk mencukupi kebutuhan dasar makanan dan bukan makanan yang di ukur dengan pengeluaran. Ukuran kemiskinan yaitu menggunakan Garis kemiskinan. Yang terdiri dari garis kemiskinan makanan (GKM), dan garis kemiskinan non makanan (GKNM).

\section{Pengertian PDRB}

Produk Domestik Regional Bruto (PDRB) didefinisikan sebagai jumlah nilai tambah yang dihasilkan oleh seluruh unit usaha dalam suatu wilayah, atau merupakan jumlah seluruh nilai barang dan jasa akhir yang dihasilkan oleh seluruh unit ekonomi di suatu wilayah. Produk Domestik Regional Bruto (PDRB) dapat menggambarkan kemampuan suatu daerah mengelola sumber daya alam yang dimilikinya. Oleh karena itu, besaran Produk Domestik Regional Bruto (PDRB) yang dihasilkan oleh masing-masing daerah sangat bergantung kepada potensi faktor-faktor produksi di daerah tersebut. Adanya keterbatasan dalam penyediaan faktorfaktor produksi tersebut menyebabkan besaran Produk Domestik Regional Bruto (PDRB) bervariasi antar daerah (Sukirno, 2000).

\section{Pengertian tingkat pendidikan}

Menurut Notoatmodjo (2010) pendidikan adalah upaya persuasi atau pembelajaran kepada masyarakat, agar masyarakat mau melakukan tindakan-tindakan (praktik) untuk memelihara (mengatasi masalah- masalah), dan meningkatkan kesehatannya. Perubahan atau tindakan pemeliharaan dan peningkatan kesehatan yang dihasilkan oleh pendidikan kesehatan ini didasarkan kepada pengetahuan dan kesadarannya melalui proses pembelajaran, sehingga perilaku tersebut diharapkan akan berlangsung lama (long lasting) dan menetap (langgeng), karena didasari oleh kesadaran.

\section{Pengertian pengangguran}

Menurut Sadono Sukirno dalam Permana (2012), pengangguran dapat diartikan seseorang yang sudah digolongkan dalam angkatan kerja secara aktif sedang mencari pekerjaan pada suatu tingkat upah tertentu, melainkan tidak dapat memperoleh pekerjaan yang diinginkan.

\section{Kerangka Konseptual}

Dalam konteks penelitian ini, aspek-aspek yang diukur dari tingkat kemiskinan Masyarakat Kabupeten Padang Pariaman ini meliputi : Produk Domestik Regional Bruto (PDRB) (X1), Tingkat Pendidikan (X2), Pengangguran (X3) terhadap Kemiskinan (Y).

\section{Gambar 2.1}


Kerangka Konseptual

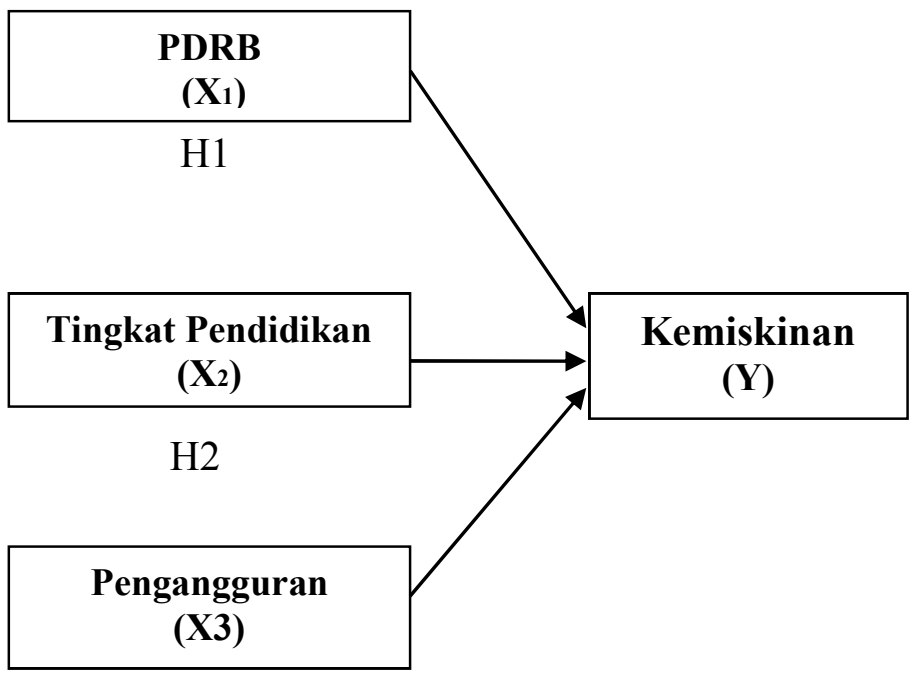

H3

\section{Hipotesis}

$\mathbf{H}_{1}$ : Ada pengaruh dari Produk Domestik Regional Bruto (PDRB) terhadap tingkat kemiskinan di Provinsi Sumatra Barat pada tahun 2012-2018.

$\mathbf{H}_{2}$ : Ada pengaruh antara tingkat pendidikan terhadap tingkat kemiskinan Di Provinsi Sumatra Barat pada tahun 2012-2018.

$\mathbf{H}_{3}$ : Ada pengaruh dari tingkat pengangguran terhadap tingkat kemiskinan Di Provinsi Sumatra Barat pada tahun 2012-2018.

\section{METODE PENELITIAN \\ Lokasi Penelitian}

Objek dalam penelitian ini adalah di Provinsi Sumatra barat.

Populasi dalam penelitian ini adalah 19 (Sembilan belas) Kabupaten dan Kota yang ada di Provinsi Sumatra Barat. Sedangkan sampel dalam penelitian ini adalah seluruh penduduk miskin di Kabupaten dan Kota Provinsi Sumatra Barat.

\section{Jenis dan Sumber data}

Data yang dipergunakan dalam penelitian ini adalah data sekunder. Data sekunder yang digunakan adalah penggabungan dari deret berkala (time series) dari tahun 2012-2018 dan deret lintang (cross section) sebanyak 19 data mewakili kabupaten/kota di Provinsi Sumatra Barat yang menghasilkan 140 observasi.

\section{Sumber data}

Sumber data yang digunakan dalam penelitian ini adalah skunder bersumber pada Badan Pusat Statistik (BPS) Provinsi Sumatra Barat.

\section{Teknik Analisis Data}

Dalam upaya mengelola data serta menarik kesimpulan maka penelitian ini menggunakan program SPSS version 23.00 for windows.

\begin{abstract}
Analisis Kualitatif
Dimaksudkan untuk menganalisis data yang tidak ada hubunganya dengan perhitungan angkaangka (Sutrisno Hadi, 2002). Penyajian berupa keterangan, penjelasan serta pembahasan secara teoritis.
\end{abstract}

\section{Statistik Deskriptif}

Statistik deskriptif adalah statistik yang digunakan untuk menganalisis data dengan cara mendeskripsikan atau menggambarkan data yang telah terkumpul sebagaimana adanya tanpa bermaksud membuat kesimpulan yang berlaku untuk umum atau generalisasi. Dalam statistik deskriptif antara lain adalah penyajian data melalui tabel, grafik, diagram lingkaran, pictogram, perhitungan modus, median, mean (pengukuran tendesi sentral), perhitungan desil, persentil, perhitungan penyebaran data melalui perhitungan rata-rata dan standar deviasi, perhitungan persentase. (Sugiyono,2012:207208).

\section{Uji Asumsi Klasik}

Suatu model regresi dikatakan linier harus melalui uji asumsi klasik yang terdiri dari uji normalitas, uji linieritas, uji multi kolinieritas dan uji heteroskedasitas ( Ghozali, 2011 )

\section{Uji normalitas}

Uji normalitas untuk menguji apakah dalam model regresi, variable pengganggu atau residual memiliki distribusi normal. Seperti diketahui bahwa nilai residual mengikuti distribusi normal. Kalau asumsi ini dilanggar maka uji statistic menjadi tidak valid untuk jumlah sampel kecil (Gozhali, 2011). 
Uji Multikolinieritas

Menurut Imam Ghozali (2011:105-106) uji multikolinieritas bertujuan untuk menguji apakah model regresi ditemukan adanya korelasi antar variabel bebas (independen).

\section{Uji Heteroskedastisitas}

Uji heterokodesitas bertujuan menguji apakah dalam model regresi terjadi ketidak samaan variabel dari residual satu pengamatan ke pengamatan yang lain. Jika varian dari residual satu pengamatan ke pengamatan lain tetap, maka disebut homoskodesitas dan jika berbeda disebut heteroskedastisitas.

\section{Uji model}

\section{Koefisien Determinasi $\left(R^{\mathbf{2}}\right)$}

Koefisien determinasi ( $\left.R^{2}\right)$ pada intinya mengukur seberapa jauh kemam puan model dalam menerangkan variasi variabel dependen. Nilai koefisien determinasi adalah antara nol dan satu.

\section{Koefisien Regresi Berganda}

Analisis ragresi berganda adalah analisi tentang hubungan antara satu dependen variabel dengan dua atau labih independen variabel.

\section{Uji F (F-test)}

Uji f dilakukan untuk menguji apakah model yang digunakan signifikan atau tidak, sehingga dapat dipastikan apakah model tersebut digunakan untuk memprediksi pengaruh variabel independen terhadap variabel dependen Ghozali (2011:98).

\section{Uji Hipotesis (uji t statistik)}

Menurut Ruswan anwar (2011) dalam "teori sederhana prosedur pemilihan uji hipotesis", Uji hipotesis digunakan untuk melihat pengaruh dari masing-masing variabel bebas secara individu terhadap variabel terikat.

\section{ANALISIS DAN PEMBAHASAN}

\section{Gambaran umum Provinsi Sumatra Barat}

Provinsi Sumara Barat adalah salah satu provinsi provinsi yang ada di Indonesia, Pulau Sumatra dengan Padang sebagai ibu kotanya. Provinsi Sumatra Barat terletak sepanjang pesisir barat Sumatra bagian tengah, dataran tinggi Bukit Barisan di sebelah timur, dan sejumlah pulau di lepas pantainya seperti Kepulauan Mentawai. Dari utara ke selatan, provinsi dengan wilayah seluas $42.297,30 \mathrm{~km}^{2}$. Jumlah kabupaten dan kota yang ada di Provinsi Sumatra Barat berjumlah 19.

\section{Statistik Deskriptif}

Statistik deskriptif memberikan gambaran atau deskripsi suatu data yang dilihat dari nilai rata-rata (mean), standar deviasi, varian, maksimum, minimum, sum, range,kurtosis dan skewness ( kemencengan distribusi) dari masingmasing variabel, (Ghozali,2011)

\begin{tabular}{|c|c|c|c|c|c|}
\hline \multicolumn{6}{|c|}{ Descriptive Statistics } \\
\hline & $\mathrm{N}$ & $\begin{array}{c}\text { Minim } \\
\text { um }\end{array}$ & Maximum & Mean & Std. Deviation \\
\hline & $\begin{array}{l}\text { Stati } \\
\text { stic }\end{array}$ & $\begin{array}{c}\text { Statisti } \\
\text { C }\end{array}$ & Statistic & $\begin{array}{l}\text { Std. } \\
\text { Error }\end{array}$ & Statistic \\
\hline$y=k e m i s$ & & & & 116,395 & 1342,340209 \\
\hline kinan & & & & 6578 & 0 \\
\hline$x 1=P D R$ & & & 4412493,0 & 93434,8 & 1077542,932 \\
\hline B & & & 000 & 219783 & 9870 \\
\hline$x 2=$ pen & & 304,00 & 31611,000 & 781,958 & 9017,984021 \\
\hline didikan & & 00 & 0 & 3850 & 3 \\
\hline$x 3=$ pen & & 597,00 & & 153,509 & 1770,355389 \\
\hline ganggur & 133 & 00 & $1 / 10 /, 0000$ & 2808 & 5 \\
\hline & & & & & \\
\hline Valid N & & & & & \\
\hline (listwise & 133 & & & & \\
\hline & & & & & \\
\hline
\end{tabular}

1. output tabel 4.1 sebelumnya menunjukan nilai $\mathrm{N}$ atau jumlah data yang akan diteliti berjumlah 133 sampel. Tingkat kemiskinan memiliki nilai mean atau rata-rata sebesar 116,3956578, yang artinya rata-rata kontribusi terhadap 
Provinsi Sumatra Barat sebesar 116,39 $\%$, dengan nilai maximum sebesar 4443,0 \% pada kurun waktu 2012-2018.. Nilai minimum $6,0 \%$ pada tahun 20122018 Dengan standar deviasi sebesar 1342,3402090 yang berarti bahwa besar peningkatan maksimum rata-rata variabel kemiskinan adalah $+1342,3402090$, sedangkan penurunan maksimum dari rata-rata variabel kemiskinan adalah $-1342,3402090$ atau dapat dikatakan rata-rata nilai penyimpangan variabel kemiskinan adalah 1342,34\%.

2. Variabel independen PDRB berjumlah 133 sample. Dengan nilai mean atau rata-ratanya sebesar Rp 93.4348.219.783. Nilai maksimum sebesar Rp 4.412.493,00 pada tahun 2012-2018 oleh Provinsi Sumatra Barat. Nilai minimum sebesar 0,000 pada tahun 2012-2018 Dengan standar deviasi Rp 10.775.429.329.870 yang berarti bahwa besar peningkatan maksimum rata-rata variabel pajak daerah sebesar $+\mathrm{Rp}$ 10.775.429.329.870, sedangkan penurunan maksimum dari rata-rata variabel pajak daerah sebesar - Rp 10.775.429.329.870

3. Variabel independen tingkat pendidikan berjumlah 133 sample. Dengan nilai mean atau rata-ratanya sebesar 781,9583850. Yang berarti nilai rata-rata sebesar 781,95 \%. Nilai maksimum sebesar 31611,0000 pada tahun 20122018 oleh Provinsi Sumatra Barat. Nilai minimum sebeartinya sar 0,000 pada tahun 2012-2018 Dengan standar deviasi 9017,9840213 yang berarti bahwa besar peningkatan maksimum rata-rata variabel pajak daerah sebesar $+9017,9840213$, sedangkan penurunan maksimum dari rata-rata variabel pajak daerah sebesar - 9017,9840213.

4. Variabel independen tingkat pengangguran berjumlah 133 sample. Dengan nilai mean atau rata-ratanya sebesar 153,5092808. Yang berarti nilai rata-rata sebesar $153,50 \%$. Nilai maksimum sebesar 7767,0000 pada tahun 2012-2018 oleh Provinsi Sumatra Barat. Nilai minimum sebesar 597,0000 pada tahun 2012-2018 Dengan standar deviasi 1770,3553895 yang berarti bahwa besar peningkatan maksimum rata-rata variabel pajak daerah sebesar $+1770,3553895$, sedangkan penurunan maksimum dari rata-rata variabel pajak daerah sebesar - 1770,3553895.

\section{Uji Normalitas}

Uji normalitas bertujuan untuk menguji apakah dalam model regeresi data terdistribusi secara normal atau tidak. Model regresi yang baik dimana distribusi datanya mengikuti distribusi normal atau mendekati normal.

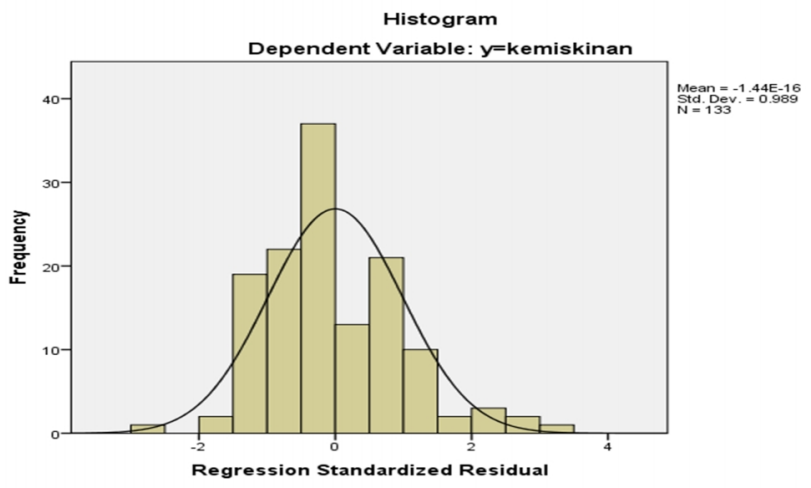

Berdasarkan gambar 4.1, grafik histogram di atas dapat dilihat bahwa data observasi terdistribusi dengan normal dimana grafik mengikuti garis diagonal, Oleh karena itu uji normalitas terpenuhi.

\section{Uji Linieritas}

Uji linieritas digunakan untuk melihat apakah spesifikasi model yang digunakan untuk melihat spesifikasi model yang digunakan sudah benar atau tidak. Untuk menentukan apakah fungsi persamaan regresi yang digunakan berbentuk linier, maka dapat dilihat pada P-P Plot. Apabila titik-titik terdistribusi mengikuti garis linier, maka model regresi dapat dinyatakan linier. 


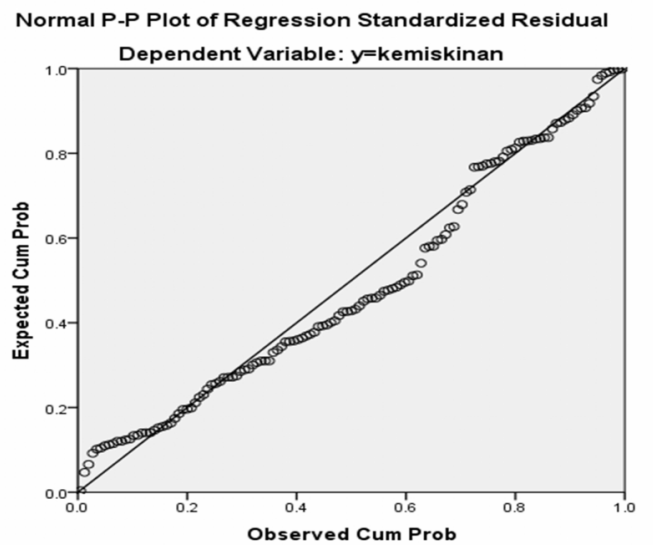

Berdasarkan gambar 4.2 di atas dapat dilihat bahwa grafik

terlihat bahwa titik-titik bergerak menuju searah dengan garis linier, sehingga dapat disimpulkan bahwa model regresi penelitian ini adalah linier.

\section{Uji Multikolinieritas}

Multikolinearitas merupakan keadaan dimana terdapat hubungan linear atau terdapat korelasi antar variabel independen. Multikolinearitas akan terjadi jika korelasi antar variabel bebas menunjukkan nilai yang sangat tinggi yaitu melebihi dari nilai angka 10.

\begin{tabular}{|r|r|}
\hline \multicolumn{2}{|c|}{ Collinearity Statistics } \\
\hline Tolerance & VIF \\
\hline & \\
.877 & \\
.873 & 1.141 \\
.995 & 1.146 \\
& 1.005 \\
\hline
\end{tabular}

Pada tabel 4.1 di atas dapat dilihat bahwa nilai VIF tidak ada yang melebihi dari angka 10 . Dengan demikian tidak terjadi multikolinearitas karena nilai tersebut masih jauh di bawah 10 .

\section{Uji Heteroskedastisitas}

uji Heteroskedastisitas bertujuan menguji apakah dalam model regresi terjadi ketidaksamaan varian dari residual satu pengamatan ke pengamatan yang lainya. Jika varian dari residual satu pengamatan ke pengamatan lainya tetap, maka disebut homoskedastisitas dan jika berbeda disebut heteroskedastisitas

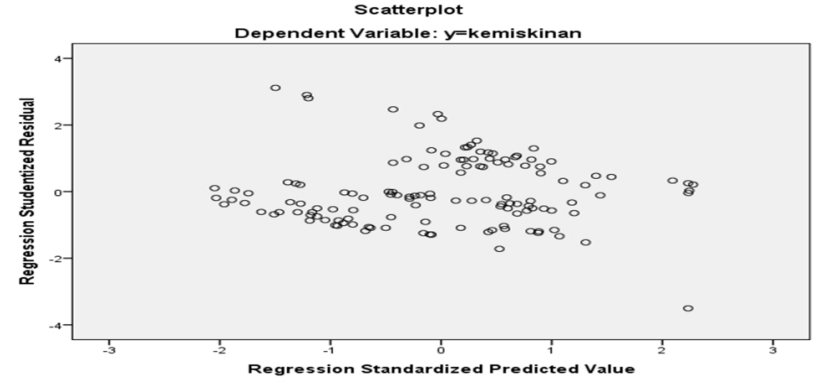

Berdasarkan gambar 4.3 di atas dapat dilihat model regresi penelitian ini tidak terjadai Heteroskedastisitas. Hal ini dapat dilihat dari grafik Plott dimana titik-titik acak menyebar diatas dan di bawah angka 0 (nol) pada sumbu Y sehingga tidak memperlihatkan pola yang jelas.

\section{Hasil Analisis Data \\ Koefisien Regresi Berganda}

Tabel 4.3

Hasil Uji Regresi Linier Berganda

\begin{tabular}{|l|r|r|}
\hline \multirow{2}{*}{ Model } & \multicolumn{2}{|c|}{ Unstandardized Coefficients } \\
\cline { 2 - 3 } & \multicolumn{1}{|c|}{$\mathrm{B}$} & \multicolumn{1}{c|}{ Std. Error } \\
\hline (Constant) & 4.336 & .471 \\
x1=pdrb & -1.001 & .310 \\
x2=pendidikan & -.494 & .210 \\
x3=pengangguran & .006 & .038 \\
\hline
\end{tabular}

Berdasarkan tabel 4.2 di sebelumnya dapat diketahui persamaan regresi yang berbentuk sebagai berikut :

$Y=a+b 1 X_{1}+b 2 X_{2}+b 3 X_{3}+\epsilon$

$Y=4,336+(-1,001) X_{1}+\left(-0,494 X_{2}\right)+0,086 X_{3}+\epsilon$

Keterangan :

$\mathrm{Y}=$ Tingkat Kemiskinan

$X_{1}=$ Produk Domestik Regional Bruto (PDRB)

$X_{2}=$ Tingkat Pendidikan

$X_{3}=$ Tingkat Pengangguran

\section{Konstan (a)}

konstanta sebesar 4,336, artinya bahwa tingkat kemiskinan akan konstan sebesar 4,336 jika tidak dipengaruhi variabel Produk Domestik Regional 
Bruto (PDRB), Tingkat Pendidikan dan Tingkat Pengangguran tidak ada nilainya atau 0 (nol). Maka dapat diartikan bahwa tingkat kemiskinan di Provinsi Sumatra Barat berdasarkan faktor-faktor tersebut, sehingga dapat diartikan kemiskinan dipengaruhi oleh faktor-faktor tersebut.

\section{Koefisien Regresi (b) x1}

Variabel Produk Domestik Regional Bruto (PDRB) mempengaruhi terhadap penurunan tingkat kemiskinan di Provinsi Sumatra Barat sebesar -1,001 satuan atau berpengaruh negatif, yang artinya jika Produk Domestik Regional Bruto (PDRB) semakin meningkat maka tingkat kemiskinan di Provinsi Sumatra Barat akan menurun sebesar 1,001\%. Dengan asumsi variabel bebas lainya tetap (X1,X2 dan X3 =0) atau Ceteris Paribus.

\section{Koefisien Regresi (b) x2}

Variabel tingkat pendidikan mempengaruhi terhadap penurunan tingkat kemiskinan di Provinsi Sumatra Barat sebesar -0,494 satuan atau berpengaruh negatif, yang artinya jika tingkat pendidikan semakin meningkat maka tingkat kemiskinan di Provinsi Sumatra Barat akan menurun sebesar 0,494\%. Dengan asumsi variabel bebas lainya tetap (X1,X2 dan X3 =0) atau Ceteris Paribus.

\section{Koefisien Regresi (b) x3}

Variabel tingkat pengangguran mempengaruhi terhadap penurunan tingkat kemiskinan di Provinsi Sumatra Barat sebesar 0,006 saatuan atau berpengaruh positif, yang artinya jika tingkat pengangguran menurun maka tingkat kemiskinan di Provinsi Sumatra Barat akan menurun sebesar $0,006 \%$ satuan. Dengan asumsi variabel bebas lainya tetap (X1,X2 dan X3) atau ceterins paribus.

\section{Uji F Statistik}

Menurut sugiyono (2011), Uji f pada dasarnya menunjukan apakah semua variabel bebas yang dimasukan dalam model mempunyai pengaruh secara bersama-sama terhadap variabel terikat. Uji f dalam

penelitian ini digunakan untuk melihat pengaruh variabel independen diantaranya PDRB (X1), tingkat pendidikan (X2), dan tingkat pengangguran (X3) terhadap variabel dependen tingkat kemiskinan (Y) di Provinsi Sumatra Barat.

Tabel 4.4

\section{Hasil Uji F Statistik}

Tabel 4.4

\section{Hasil Uji F Statistik}

\begin{tabular}{|c|c|c|c|c|c|}
\hline \multicolumn{6}{|c|}{ ANOVA $^{a}$} \\
\hline Model & $\begin{array}{l}\text { Sum of } \\
\text { Squares }\end{array}$ & Df & $\begin{array}{l}\text { Mean } \\
\text { Square }\end{array}$ & $\mathrm{F}$ & Sig. \\
\hline 1 Regression & 6628.319 & 3 & 2209.440 & 16.704 & $.000^{b}$ \\
\hline Residual & 17062.844 & 129 & 132.270 & & \\
\hline Total & 23691.163 & 132 & & & \\
\hline
\end{tabular}

Berdasarkan tabel 4.4 sebelumnya bahwa Hasil pengolahan data menunjukan nilai signifikan sebesar $0,000<0,05$ berarti nilai signifikansi lebih kecil dari 0,05. Maka dapat disimpulkan bahwa variabel independen berpengaruh terhadap variabel dependen , dan model yang digunakan bias diandalkan atau sudah fix.

Koefisein Determinasi $\left(\boldsymbol{R}^{2}\right)$

\section{Tabel 4.5}

Hasil Uji Koefisien Determinasi $\left(R^{2}\right)$ Model Summary ${ }^{\text {b }}$

\begin{tabular}{|l|l|r|r|r|r|}
\hline $\begin{array}{l}\text { Mo } \\
\text { del }\end{array}$ & $\mathrm{R}$ & $\begin{array}{c}\mathrm{R} \\
\text { Square }\end{array}$ & $\begin{array}{c}\text { Adjusted } \\
\text { R Square }\end{array}$ & $\begin{array}{c}\text { Std. Error of } \\
\text { the } \\
\text { Estimate }\end{array}$ & $\begin{array}{c}\text { Durbin- } \\
\text { Watson }\end{array}$ \\
\hline 1 & $.529^{\mathrm{a}}$ & .280 & .263 & 11.5008743 & .341 \\
\hline
\end{tabular}

Dari tabel 4.4 di atas dapat dilihat hasil regresi pengaruh pertumbuhan PDRB, tingkat pendidikan dan tingkat pengangguran terhadap tingkat kemiskinan di Provinsi Sumatera Barat tahun 2012-2018 pada tabel diperoleh nilai R Squere sebesar 0,280. Hal ini berarti sebesar 28 persen variasi tingkat kemiskinan dapat dijelaskan oleh 3 variabel independen yaitu variabel PDRB, tingkat pendidikan dan tingkat pengangguran Sedangkan sisanya sebesar 72 persen dijelaskan oleh variabel lain di luar model.

\section{Pengujian Hipotesis (uji t Statistik)}

Menurut Ruswan anwar (2011) dalam "teori sederhana prosedur pemilihan uji hipotesis" Uji t dilakukan untuk mengetahui pengaruh variabel independen terhadap variabel dependen dalam persamaan regresi secara parsial dengan asumsi variabel lain dianggap konstan.

Dengan ketentuan sebagai berikut :

a. Jika nilai sig $<\alpha$, maka $\mathrm{H} 0$ diterima dan $\mathrm{Ha}$ di tolak, berarti ada hubungan signifikan antara variabel independen dengan variabel dependen. 
b. Jika nilai sig $>\alpha$, maka $\mathrm{H} 0$ ditolak dan $\mathrm{Ha}$ di terima, berarti tidak ada hubungan signifikan antara variabel independen dengan variabel dependen.

Hasil pengujian menunjukan bahwa tingkat alpha 0,05 diperoleh kesimpulan sebagai berikut :

1. H1 : Pengaruh Produk Domestik Regional Bruto (PDRB) berpengaruh negatif terhadap tingkat kemiskinan di Provinsi Sumatra Barat. dari tabel 4.3 dapat dilihat bahwa PDRB (X1) memiliki nilai signifikan $0,003<0,05$. Hal ini menunjukan bahwa PDRB berpengaruh terhadap tingkat kemiskinan, jadi hipotesis 1 (satu) diterima.

2. H2 : Tingkat Pendidikan berpengaruh negatif terhadap tingkat kemiskinan di Provinsi Sumatra Barat. dari tabel 4.3 dapat dilihat bahwa Tingkat Pendidikan (X2) memiliki nilai signifikan 0,029 $<0,05$. Hal ini menunjukan bahwa Tingkat Pendidikan berpengaruh terhadap tingkat kemiskinan, jadi hipotesis 2 (satu) diterima.

3. H3 : Tingkat Pengangguran berpengaruh negatif terhadap tingkat kemiskinan di Provinsi Sumatra Barat. dari tabel 4.3 dapat dilihat bahwa Tingkat Pengangguran (X3) memiliki nilai signifikan $0,005<0,05$. Hal ini menunjukan bahwa Tingkat Pengangguran berpengaruh terhadap tingkat kemiskinan, jadi hipotesis 3 (satu) diterima.

\section{PENUTUP}

Berdasarkan pembahasan hasil penelitian pada Rumah Makan Kiambang Raya Dapat disimpulkan:

1. Faktor Produk Domestik Regional Bruto (PDRB) berpengaruh signifikan terhadap penurunan tingkat kemiskinan di Provinsi Sumatra Barat, karena nilai signifikansi bernilai sig 0,003 kecil dari pada Level of significant (a) 0,05 .

2. Faktor tingkat pendidikan berpengaruh signifikan terhadap penurunan tingkat kemiskinan di Provinsi Sumatra Barat, karena nilai signifikansi 0,029 kurang dari pada Level of significant (a) 0,05 .

3. Faktor tingkat pengangguran berpengaruh signifikan positif terhadap penurunan tingkat kemiskinan di Provinsi Sumatra Barat, karena nilai signifikansi positif yaitu 0,005 kecil dari pada Level of significant (a) 0,05 .
Berdasarkan hasil penelitian dan kesimpulan diatas, maka penelitian perlu memberikan saran-saran sebagai berikut :

1. Diharapkan pemerintah Provinsi Sumatra Barat kedepanya dapat dilaksanakan pembangun yang berorientasi pada pemerataan pendapatan serta pemerataan hasil-hasil ekonomi keseluruh golongan masyarakat.

2. Diharapkan pemerintah Provinsi Sumatra Barat Memberikan jaminan pendidikan bagi orang miskin yang berprestaasi serta meningkatkan fasilitas-fasilitas pendidikan secara merata, tidak hanya terpusat di suatu daerah tetapi merata ke seluruh daerah lainnya.

3. Diharapkan Pemerintah Provinsi Sumatra Barat dapat menciptakan lapangan kerja yang mampu menampung lebih banyak lagi pekerja dan Diskriminasi instansi perusahaan/ pemerintahan dalam merekrut pegawai atau karyawan hendaknya dihilangkan, perekrutan yang benar-benar berdasarkan atas kemammpuan bukan atas dasar kekerabatan, ras, suku, agama dan lainnya.

4. Untuk peneliti selanjutnya yang tertarik dengan masalah yang sama diharapkan mampu mengungkap, menambah dan melengkapi apa saja faktor-faktor yang berpengaruh terhadap tingkat kemiskinan khususnya di Provinsi Sumatra Barat.

\section{DAFTAR PUSTAKA}

Windra, Marwoto, \& Rafani, 2016. Pertumbuhan ekonomi, faktor yang mempengaruhi suatu bangsa untuk memajukan bangsanya atau menaikan kesejahteraan warganya.

Peraturan Pemerintah (PP) nomor 79 tahun 2008 tanggal 30 Desember 2008 tentang pemindahan Ibukota Kabupaten Padang Pariaman.

Prastyo (2012). Kemiskinan adalah suatu intergrated concept yang memiliki lima dimensi.

Hidiyanto, 2014. Ukuran kemiskinan dibedakan dalam dua bentuk Kemiskinan absolut (absolute poverty) dan Kemiskinan relative.

BPS (Badan Pusat Statistik) Sumatra Barat, 2018. Jumlah Penduduk Miskin Kabupaten/Kota Sumatera Barat Tahun 2014-2018 .

\section{SARAN}


BPS (Badan Pusat Statistik), 2018. Jumlah Penduduk Miskin Kabupaten Padang Pariaman Tahun 2014-2018.

BPS (Badan Pusat Statistik), 2018. PDRB (Produk Domestik Regional Bruto), Pendidikan dan Tingkat Partisipasi Angkatan Kerja (TPAK) Dan Tingkat Pengangguran Terbuka (TPT) Di Kabupaten Padang Pariaman Tahun 20122018.

Nenik Woyanti (2018) dalam penelitiannya yang berjudul " Pengaruh PDRB, Pendidikan, Kesehatan, dan Penganggruran Terhadap Tingkat Kemiskinan di Jawa Tengah (20112015)".

M.Alhudori (2017) dalam penelitiannya yang berjudul " Pengaruh IPM, PDRB dan Pengangguran TErhadap Penduduk Miskin di Provinsi Jambi”.

Himawan Yudistira Dama, Agnes L Ch Lapian, Jacline I.Sumual (2016) dalam skripsinya" Pengaruh Produk Domestik Regional Bruto (PDRB) Terhadap Terhadap Kemiskinan di Kota Manado Tahun 2014-2015”

Mudrajat Kuncoro dalam Dian Adi Wibowo (skripsi,2013) mengatakan bahwa kemiskinan merupakan ketidakmampuan untuk memenuhi standar hidup minimum.

Harry. (2010) dalam Nurwati. (2012). Kemiskinan dapat di bedakan menjadi dua, Kemiskinan kronis dan kemiskinan sementara.

Suryawati, (2014) kemiskinan dapat di lihat dari ciriciri kelompok penduduk .

Suwadi, (2014:25). Kemiskinan di sebabkan oleh dua hal antara lain yang pertama Kemiskinan di sebabkan karena sifat alami, sifat yang timbul dari perilaku masyarakat atau seseorang.

Menurut Badan Pusat Statistik Ponorogo (2016) kemiskinan dapat di lihat dengan ca ra menggunakan perhitungan Head Count index.

Suwadi $(2012 ; 34)$ berpendapat bahwa pertumbuhan ekonomi di pengaruhi oleh berbagai factor.
Notoatmodjo, (2010). pendidikan adalah upaya persuasi atau pembelajaran kepada masyarakat, agar masyarakat mau melakukan tindakan-tindakan (praktik) untuk memelihara (mengatasi masalah- masalah), dan meningkatkan kesehatannya.

Jundi ,(2014). bahwa Pendidikan merupakan sarana untuk menghapuskan kebodohan, pendidikan sendiri memiliki beberapa jenjang pendidikan seperti SD, SMP, SMA, dan Perguruan Tinggi sederajat.

UU No 20 Tahun 2003. Terdapat beberapa jalur pendidikan di Indonesia, Pendidikan formal , non formal dan Pendidikan informal.

Sukirno dalam Permana (2012). pengangguran dapat diartikan seseorang yang sudah digolongkan dalam angkatan kerja secara aktif sedang mencari pekerjaan.

Sholekah (2016) bahwa ada beberapa teori menjelaskan tentang teori-teori pengangguran.

Ahmad Soleh (Tahun 2018) "Analisis dan Strategi pengentasan Kemiskinan di Provinsi Jambi”.

Dahma Amar Ramadhan, Djoko Styadi, Adi Wijaya, ( 2017). "Faktor-faktor yang mempengaruhi tingkat pengangguran dan kemiskinan di kota samarinda".

Ziyadaturrofiqoh, Zulfanetti, Muhammad Safri, (2018). "Pengaruh PDRB, Upah Minimum Provinsi dan Pengeluaran Pemerintah Terhadap Penyerapan Tenaga Kerja di Provinsi Jambi”.

Sindi Paramita Sari (2016). "Analisis PDRB tingkat pendidikan dan tingkat pengangguranterhadap tingkat kemiskinan di Provinsi Sumatra Selatan.

Edyson Susanto, Eny Rochaida, Yana (2016). Ulfah Pengaruh inflasi dan pendidikan terhadap pengangguran dan kemiskinan". 